\title{
The impact of the introduced Digitonthophagus gazella on a native dung beetle community in Brazil during 26 years
}

\author{
Walter Mesquita Filho $\sqrt{ }$ - Carlos A. H. Flechtmann • Wesley. A. C. Godoy • \\ Ottar N. Bjornstad
}

Received: 7 December 2016/Accepted: 26 October 2017/Published online: 30 October 2017

(C) Springer International Publishing AG 2017

\begin{abstract}
Following successful establishment in Australia and North America, the South African dung beetle (DB) Digitonthophagus gazella was introduced in Brazil in 1990. We investigated the impact of the exotic species on the native community of 42 native DB species using a unique weekly data set spanning 26 years, including 4 years of pre-invasion data. The invasion of $D$. gazella was very rapid with abundances increasing by 4 orders of magnitude during the first few years following establishment. We show that the DB diversity shrank to sixty percent of the preinvasion level. Results from multivariate analyses identified three distinct periods of changes in composition and abundance: before the invasion (BI); after
\end{abstract}

Electronic supplementary material The online version of this article (https://doi.org/10.1007/s10530-017-1603-1) contains supplementary material, which is available to authorized users.

W. M. Filho $(\bowtie) \cdot$ Wesley. A. C. Godoy

Departamento de Entomologia e Acarologia, Escola Superior de Agricultura Luiz de Queiroz, Universidade de São Paulo (USP), Piracicaba, SP CEP 13418-900, Brazil e-mail:wmesquitafilho@gmail.com

C. A. H. Flechtmann

Departamento de Fitossanidade, Faculdade de Engenharia, Universidade Estadual Paulista (UNESP), Ilha Solteira, SP CEP 15385-00, Brazil

O. N. Bjornstad

Departments of Entomology and Biology, Penn State

University, University Park, PA 16802, USA invasion I (AI-I); and AI-II each one characterized by a particular dynamic of the native species. The impacts on the native species differed according to their nesting behavior. Species with the same behavior as $D$. gazella (tunneler) became less abundant and five species went locally extinct. Dweller species, in contrast, became more abundant. Although the analysis of all species combined showed an increase in abundance and a less oscillatory dynamic in AI-II compared to BI, this was the case only for the dweller species, as the tunnelers showed a tendency to continued decrease throughout the 26-year study. Our results show that a new community was originated as a consequence of the invasion, in which dweller species, particularly Labarrus pseudolividus, are the dominant species and all the tunnelers, including $D$. gazella, are decreasing in abundance.

Keywords Scarabaeidae - Biological invasion . Invasive species $\cdot$ Native community $\cdot$ Dung beetles . Pasture area

\section{Introduction}

Dung beetles (Coleoptera, Scarabaeidae, Scarabaeinae) utilize a variety of resource for feeding and nesting, including cow pads (Halffter and Matthews 1966). In such ephemeral resources, competition can be fierce (Hanski and Cambefort 1991a). To avoid 
competition, these species developed distinct nesting behaviors, which include (a) rollers, species which make balls of dung, roll them away from the food source, and bury them in the soil; (b) tunnelers, which dig tunnels and construct nest chambers below the dung pile; and (c) dwellers, species that live freely in the droppings (Hanski and Cambefort 1991b). In addition, they have different periods of activity during the day, with diurnal, crepuscular and nocturnal species (Koskela 1979; Krell et al. 2003), different seasonal patterns (Davis 1996), different burying depths (Halffter and Edmonds 1982) and body sizes, which may facilitate coexistence (Hanski and Cambefort 1991b).

In a successful example of biological control by insects, dung beetles (Coleoptera, Scarabaeidae) from South Africa were introduced into Australia during the mid-1960s to remedy the problems caused by the accumulation of cow pads in pasture areas. Because the cow pads were not being removed from the surface, grass growth declined, which led to loss of grazing area and to an increase in abundance of cattle pests and parasites (Bornemissza 1960, 1979). Several dung beetle species with different nesting behaviors were introduced. Of the introduced species, Digitonthophagus gazella became widespread (RidsdillSmith and Edwards 2011). Due to its successful introduction in Australia and with the same objective, D. gazella was deliberately released in many countries around the world (Blume and Aga 1978; Gutierrez et al. 1988; Ripa et al. 1995), including Brazil in 1990 (Bianchin et al. 1992).

Digitonthophagus gazella sensu Génier and Moretto (2017), an African tunneler species adapted to open areas (Cambefort 1984), was able to become established in countries such as the United States and Australia. It is efficient in removing cow dung (Bornemissza 1970; Young 2007) and has the highest reproductive rate among Scarabaeinae dung beetle species with a short generation cycle (Blume and Aga 1975). Additionally, D. gazella has a good dispersal capacity (Kohlmann 1991; Seymour 1980) and a wide tolerance to climatic conditions (de Oca and Halffter 1995). Although these characteristics were responsible for the establishment of the species in areas where it was introduced, these features also made D. gazella an effective competitor and invader. This calls attention to the potential risk of invasion and establishment of this species in countries where it was not intentionally released, and to its possible negative effects on the native dung beetle fauna (Zunino and Barbero 1993; de Oca and Halffter 1998). A few years following its release in the United States, D. gazella invaded Mexico and quickly expanded its range (Barbero and Lopez-Guerrero 1992). Even though only a handful of papers have been published on the species' effect on native dung beetle communities in Mexico, the results were similar. Digitonthophagus gazella became the dominant species, and most native species decreased in abundance, with a few becoming locally extinct (Howden and Scholtz 1986; de Oca and Halffter 1995; Young 2007). However, due to the lack of pre-invasion data and the long time span between collecting times, none of these studies showed that reported changes were due to the exotic species, instead of to changes in other environmental conditions. Therefore, long-term studies that focus on invaded communities and encompass sampling before, during, and after an introduction, collecting continuously over a period of years, are needed in order to fully understand the consequences and the dynamics of this biological invasion (Blossey 1999; Strayer et al. 2006; Stricker et al. 2015).

Generally, invasions have an initial acute phase when a new species arrives and expands its territory. This is followed by a chronic phase, which may involve genetic changes in the invader and changes in the biological community of the invaded ecosystem. After various abiotic, ecological, and evolutionary changes have occurred, the former invader may become a non-dominant member of the ecosystem (Strayer et al. 2006; Blackburn et al. 2011; Zenni et al. 2017). Thus, the time since an invasion needs to be considered to understand the impacts of the invasion, because the results of the effects on the native species are dependent on when and for how long the sampling was conducted (Yelenik and D'Antonio 2013). For example, for the same invasive species, if a study is conducted during the acute phase, one may find that biological invasions lead to decreased abundance and diversity (Porter and Savignano 1990). However, if the investigation is conducted during the chronic phase, one may conclude that the exotic species had a benign impact, since local original species's populations had increased to pre-invasion levels (Morrison 2002). Moreover, there may be time lags between the arrival of the exotic species and its influence on the native fauna, making long-term studies necessary in order to 
evaluate both transient and persistent effects of the invasive species (Drake 2004; Sakai et al. 2001; Crooks 2005).

A dung beetle community in a pasture area in Brazil was systematically studied over 26 years, starting the collections in 1989, before the arrival of D. gazella (Flechtmann et al. 1995a, b, c, d, e), and extending them up to 2015. Dung beetles were sampled using a black light trap, by field evaluations in cow pads, and by dissections of dung beetles from cow pads in the laboratory (Flechtmann et al. 1995d). These studies reported the species associated with cow pads in the area (Flechtmann et al. 1995e), evaluated the removal of dung in relation to beetle's body size (Flechtmann et al. 1995a), and compared the efficiency of the sampling methods in collecting dung beetles (Flechtmann et al. 1995b, c). In 1993, D. gazella was first collected, without being intentionally introduced in the area. Thus, we present a long-term study that comprised 26 years of weekly collection data, including 4 years preceding the invasion, conducted in the same locale. The local native dung beetle community is a specious guild, comprising more than 40 species with different nesting behaviors. Our objectives were (1) to investigate the impact of the exotic tunneler species $D$. gazella on the abundance of the native dung beetle community during the process of invasion and establishment, (2) to study the dynamics of invasion by $D$. gazella, (3) to determine how species with different nesting behaviors responded to the invasion, and (4) to evaluate the relative influence of abiotic factors and the invasive species on the observed changes.

\section{Methods}

Field area and insect collection

Since November 23, 1989 a black-light flight-intercept trap, model "Luiz de Queiroz" (Matioli and Silveira Neto 1988), equipped with an $\mathrm{F}_{15} \mathrm{~T}_{8} \mathrm{BL}$ lamp, has been used for weekly collection of insects from dusk to dawn of the next day. The trap is installed in the Research, Teaching and Extension Farm $\left(20^{\circ} 22^{\prime} 34.11^{\prime \prime} \mathrm{S}, 51^{\circ} 24^{\prime} 58.22^{\prime \prime} \mathrm{W}\right)$ owned by the São Paulo State University (UNESP) and located in Selvíria, Mato Grosso do Sul, Brazil. Dung beetles captured were identified using the reference collection of the Museum of Entomology of UNESP (MEFEIS), Ilha Solteira, state of São Paulo, Brazil, where all voucher specimens were deposited, and where their abundance was recorded. Digitonthophagus gazella was first recorded in the study area in 1993. The most likely source of pioneer invading beetles is a property about $20 \mathrm{~km}$ distant from the study area, where $D$. gazella was reared and released in the pasture.

The local climate is classified as Aw (equatorial savannah with a dry winter) according to the KöppenGeiger climate classification (Kottek et al. 2006) and the local altitude is $335 \mathrm{~m}$. During the period of the experiment, the average maximum, minimum and mean temperatures were respectively $30.91,19.43$ and $24.83{ }^{\circ} \mathrm{C}$, average air relative humidity $71.13 \%$ and annual rainfall $1384.53 \mathrm{~mm}$ (Appendix S2: Fig. S1). The rainy season extends from September through March, and the dry season from April through August. The weather variables for this analysis included the average maximum (aTmax) and minimum (aTmin) air temperatures, relative humidity $(\mathrm{RH})$, and rainfall. The total daily rainfall was recorded on the Farm where the trap is located. All other variables were collected by a data logger located $3 \mathrm{~km}$ from the collecting site. The average of each weather variable was recorded hourly, and the daily mean used in this study.

The total area of the Farm is 1158.68 ha, with 350 ha of pasture areas of the spreading liverseed grass Urochloa decumbens (Stapf). The landscape has remained the same since the mid-1970s, when the native vegetation was removed and pasture implemented. Livestock began in the early-1980s. The city of Selvíria, which is located adjacent to the Farm, has not expanded toward it since the pastures were formed in the late 1970s. Fertilizers were never heavily applied on the Farm. Only lime and superphosphate were used, and applications were occasionally made only a few times over the years, only once in a few areas, and never near the trap. Additionally, ivermectin, which is used to control ecto- and endoparasites of livestock and may be harmful to dung beetles (Verdú et al. 2015), was never used on the Farm.

\section{Data analysis}

During the 26 years of weekly data collection, only 74 weeks of data $(5.65 \%)$ were lost due to trap malfunction, poor weather conditions, or no collection 
at all. However, of these missing weeks, 44 weeks $(59.5 \%)$ were lost in dry months (March to August) when dung beetles are significantly less active. These missing data were interpolated linearly, based on the data for the preceding and following weeks.

Diversity across the years was estimated by Hill's diversity number $N_{1}$ (Hill 1973). Hill's $N_{1}$ is the exponential form of Shannon entropy $\left(H^{\prime}\right)$ and uses the numbers equivalent of species or individuals, which is a more appropriate method for measuring diversity (Ellison 2010).

Prior to all analyses, the abundance data were logtransformed, averaged across the years, and normalized to rescale the variance of all species. These statistical transformations were applied to avoid bias in the results due to the difference in the variance of the species, since some had high abundance while others had low abundances. As collections began on November 23, 1989, each year refers to the weeks between November from 1 year and November of the next year (e.g. year 1: samples from Nov. 23, 1989 to Nov. 16, 1990; year 2: samples from Nov. 23, 1990 to Nov. 16, 1991).

A variety of multivariate analyses were used to analyze the data. A principal component analysis (PCA) was carried out using the prcomp function from the stats package in the R Statistical Software (R Core Team 2015), and was used to visualize the changes in abundance and which species varied most over the years. Functional data analysis (FDA) was carried out based on the so-called empirical orthogonal function (EOF), which consists of using the loadings from the PCA as the functions that describe the general pattern of the data (Ramsay and Silverman 2005). FDA was applied to visualize the general pattern of changes in the abundance of all species, and how the abundance of the species varied in relation to the mean. Additionally, FDA was used to understand which mechanisms might be regulating the changes in abundance. Using the results of the PCA and FDA, the years were grouped as a function of similarities in the dynamics of the abundance in relation to the invasion. A linear discriminant analysis (LDA) was then applied, using the lda function from the $\mathrm{R}$ package MASS (Venables and Ripley 2002), on those groups to evaluate if the differences observed were discriminating periods with distinct dynamics. Biplots were produced, following Roy et al. (2009), enabling visualization of the distance between groups.
MANOVA was used to compare the mean of the groups. Redundancy analysis (RDA) was used in order to determine the amount of the variability explained by the exotic species and by the climate variables. RDA is an extension of multiple regression, which regresses explanatory variables (weather variables, log-transformed abundance of exotic species averaged across years (D.gaz), and years since invasion by $D$. gazella (year) on response variables (species abundance) and observations (collecting years), and provides a test of significance similar to that of a linear regression analysis (Legendre and Legendre 2012). Triplots of the results were then plotted to visualize the correlation among observations, response variables and explanatory variables. The significance of the model was tested using ANOVA, and a permutation test applied to determine which canonical axes were significant. RDA was carried out using the $r d a$ function in the $\mathrm{R}$ package vegan (Oksanen et al. 2015). A forward selection of the explanatory variables was employed using the forward.sel function in the R package packfor (Borcard et al. 2011; Dray et al. 2013).

All analyses were conducted for the following cases: (1) all dung beetle species, including and excluding the abundance of D. gazella; (2) only tunneler species, including and excluding D. gazella; and (3) only dweller species.

\section{Results}

A total of 725,605 dung beetles representing 42 species and 19 genera were collected, including $D$. gazella. The exotic species comprised $67 \%$ of the total, with more than 400,000 individuals captured. Among the native species, more than 200,000 dwellers were collected, while tunnelers totaled 27,491, and only two roller species were collected (Appendix S1: Table S1). The total abundance of each group and exotic species across the years is displayed in Fig. 1, showing the changes in the numbers of individuals of different nesting behaviors and the exotic species.

The mean maximum air temperature and rainfall increased during the period of the experiment, while mean minimum air temperature decreased and varied less through the years since year 10 (1998-1999). Relative humidity has been increasing since year 18 (2006-2007) (Appendices S2: Fig. S1). 
Fig. 1 Hill's diversity number $N_{1}$ and total abundance of native tunneler, dweller and exotic tunneler species D. gazella weekly in a black-light trap in a pasture area in Selvíria, Mato Grosso do Sul, Brazil from November 1989 to November 2015. Year corresponds to the period from November to November, and therefore year 1 encompasses the weeks from November 23 1989 to November 161990 , and so on

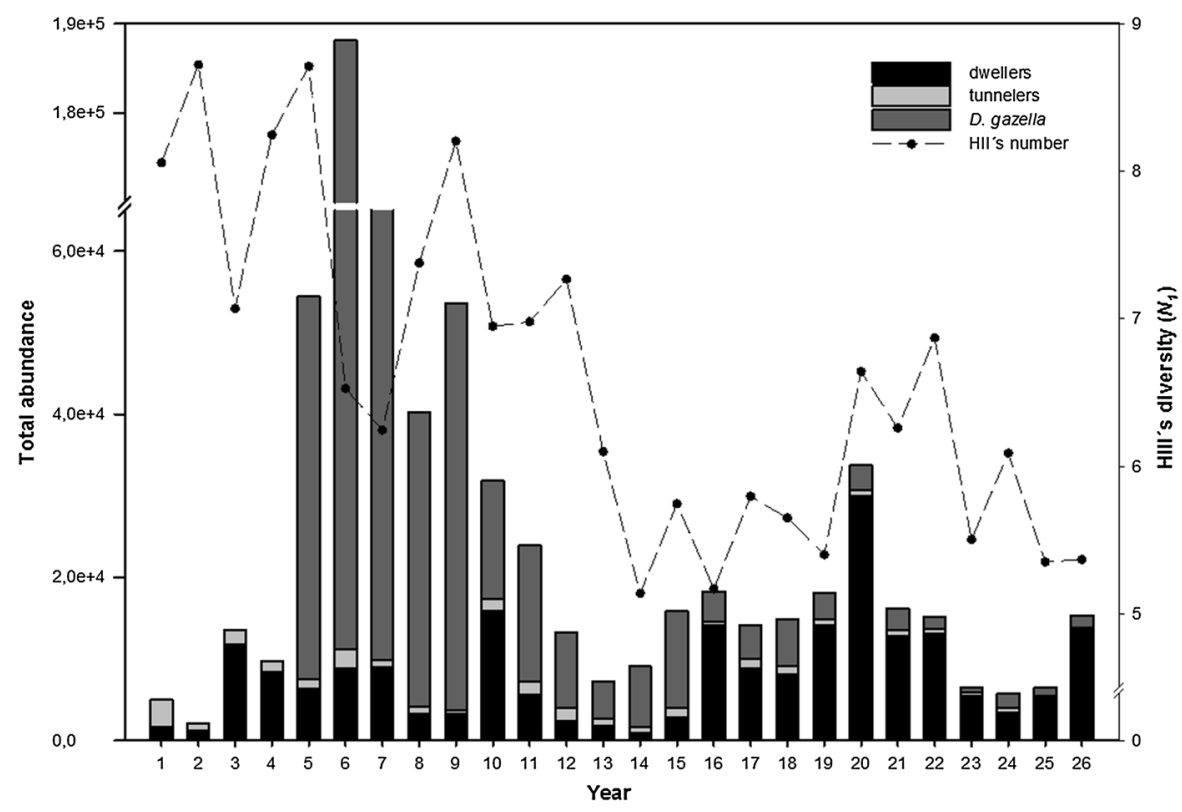

\section{Dynamics of invasion}

Our data suggest four distinct "stages" in the invasion and establishment timeline of D. gazella. Stage I was from September 19, 1993 (the first collection of this species) to February 2, 1996, and was characterized by a rapid increase in abundance, with a peak of 35,428 specimens collected in October 5, 1995, followed by a decrease in abundance. The following stage II extended until April 30, 1998 and was characterized by high abundance, but lower than in the previous stage and with no distinct peak in abundance. The same dynamic was observed in the two subsequent stages. In stage III, which extended from the end of stage II to April 26, 2001, D. gazella decreased even more in abundance. The dynamics in stage IV (from the end of stage III until the last day used in the analyses) was the same, with the exotic species continuously decreasing in numbers through the years (Fig. 2).

Impact of D. gazella on native dung beetle community

Comparing the time periods before and after invasion the results showed some species not collected before the invasion were collected afterward; other species increased in abundance for years after the invasion and then were no longer collected; and finally, some species present before the invasion were not collected again after the invasion. These last species are Canthidium nr. pinotoides, Ontherus dentatus and Ontherus sulcator (Appendix S1: Table S1).

The abundance of native species (both dwellers and tunnelers) decreased sharply following the invasion. Digitonthophagus gazella was the most abundant species from right after it invaded the Farm pastures until year 15 (2004-2005), after which the native dweller species were the dominant group. Mirroring the changes in native species abundance, the diversity was higher on the 4 years before the invasion, decreasing sharply after this period until year 14 (2002-2003). Since year 15 (2003-2004) it has stabilized around a value lower than the period before the invasion (Fig. 1).

We selected the most abundant species to evaluate the possible impacts of $D$. gazella invasion on the native community. These species were the dwellers Genieridium bidens, Labarrus pseudolividus, Nialaphodius nigrita and Trichillum externepunctatum, and the tunnelers Ateuchus nr. puncticollis, Canthidium nr. pinotoides, Dichotomius bos, Dichotomius nisus, Dichotomius semiaeneus, Dichotomius sexdentatus, Ontherus appendiculatus, O. dentatus, O. sulcator, and the exotic D. gazella.

PCA and FDA were first carried out including the abundance of all native dung beetle species and $D$. gazella (hereinafter referred to as all-species analysis). The results showed that PC1 captured the variation in 


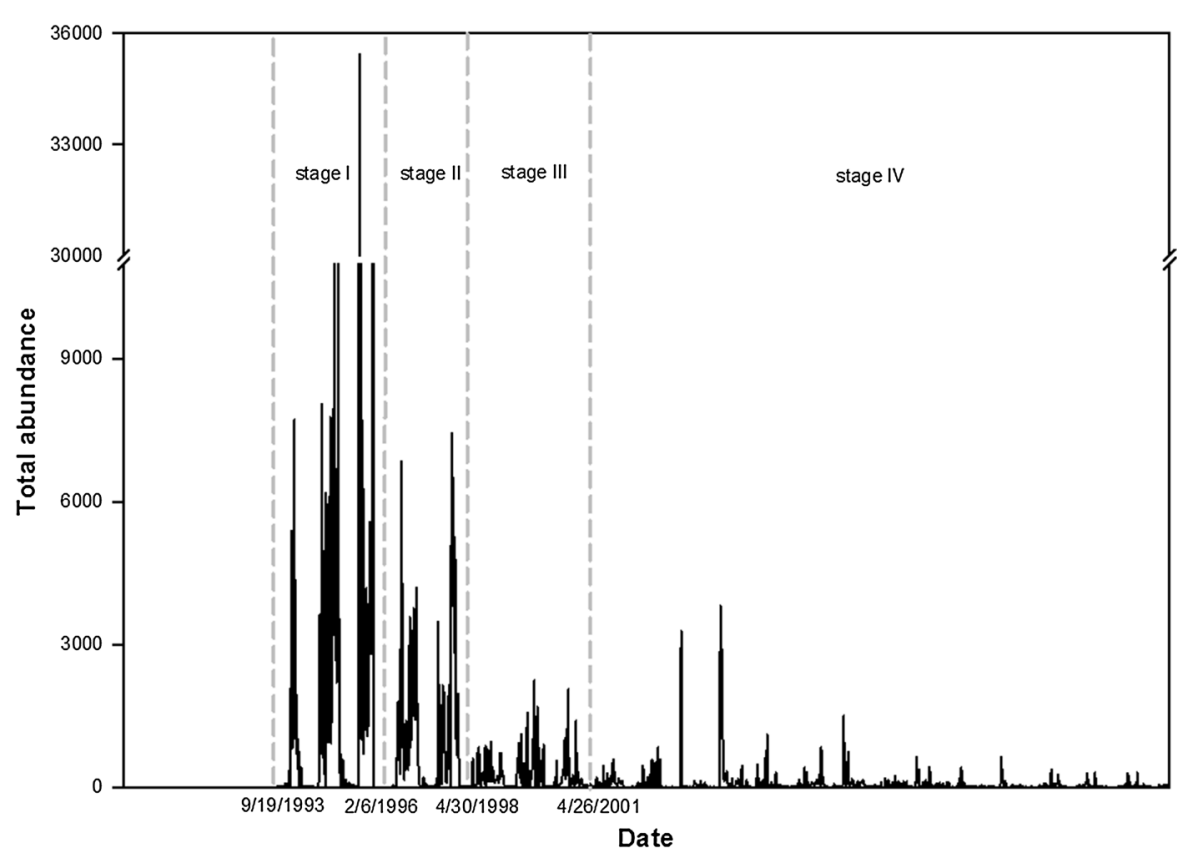

Fig. 2 Total weekly abundance of the exotic dung beetle species D. gazella collected in a black-light trap in a pasture area in Selvíria, Mato Grosso do Sul, from November 1989 to

the abundance in relation to the mean (all arrows pointing in the same direction; the so-called "meaneffect" in ordination); while PC2 captured the impact of the invasion on the abundance of native species, as the years before the invasion (years 1-4) are distinct from the remaining years along this axis. These results were confirmed by the EOF 2 plot of the FDA (Appendix S2: Fig. S2). Thus, the ordination of years and species in relation to PC2 indicates whether the species became more or less abundant after the invasion. To evaluate the impact of the exotic species on the native fauna, we performed a PCA and FDA using only the abundance of native species. Here, we focus on the results from PC2, as it is the most informative component.

Figure 3a displays the biplot from the PCA. The first two principal components captured $92.73 \%$ of the variability of the data. Ordination of the years according to the PC2 did not show a distinct separation among them. However, there was a marked difference between the species that became more abundant after the invasion (negative scores) and those that became less abundant (positive scores). In general, the impact of the exotic species varied according to the nesting behavior of the native species, since only dweller
November 2015. Stages I-IV delimit different periods in the changing dynamics of the exotic species during the process of invasion and establishment

species showed increase in abundance. Of the 13 native species analyzed, four tunneler (A. nr. puncticollis, D. bos, D. nisus and O. appendiculatus) and two dweller species ( $G$. bidens and T. externepunctatum) decreased, while two other dweller species (L. pseudolividus and $N$. nigrita) and five tunnelers (C. $n r$ pinotoides, D. semiaeneus, D. sexdentatus, O. dentatus, and $O$. sulcator) increased in abundance after the invasion. The FDA results are shown in Fig. 3b. The upper panel shows the result of EOF 2 and the bottom panel the dynamics in relation to the mean when adding or subtracting the variability from the function. This bottom plot showed that the decrease in abundance of all native species occurred beginning with the first year after the invasion, and that there were different periods in the community dynamics. Years 1-4 (1989-1993), the period prior to the invasion, were followed by 10 years of marked decreases in the abundance of the native species (years 5-14). In year 15 (2003-2004), the species rebounded in abundance, reversing the trend of a decrease in numbers to a dynamic of oscillation around a mean, and an apparent "inversion" in the prevalence of the native species occurred. This is shown in Fig. 3b, when the EOF curves change position in relation to the mean, 
Fig. 3 Bi-plot and functional data analysis (FDA) from the principal components analysis (PCA). a The bi-plot shows the results from the PCA of native dung beetle species, with the respective percentage of variance explained by each PC axis. b Upper panel corresponds to the plot of loadings from the PC2, termed EOF 2. The bottom graph is the plot of the mean abundance during the years, and the mean abundance with added (red) and subtracted (blue) variability from the EOF 2 , which show the functional response of species abundance in relation to the observed mean. See Appendix S1: Table S2 for abbreviations
(A)

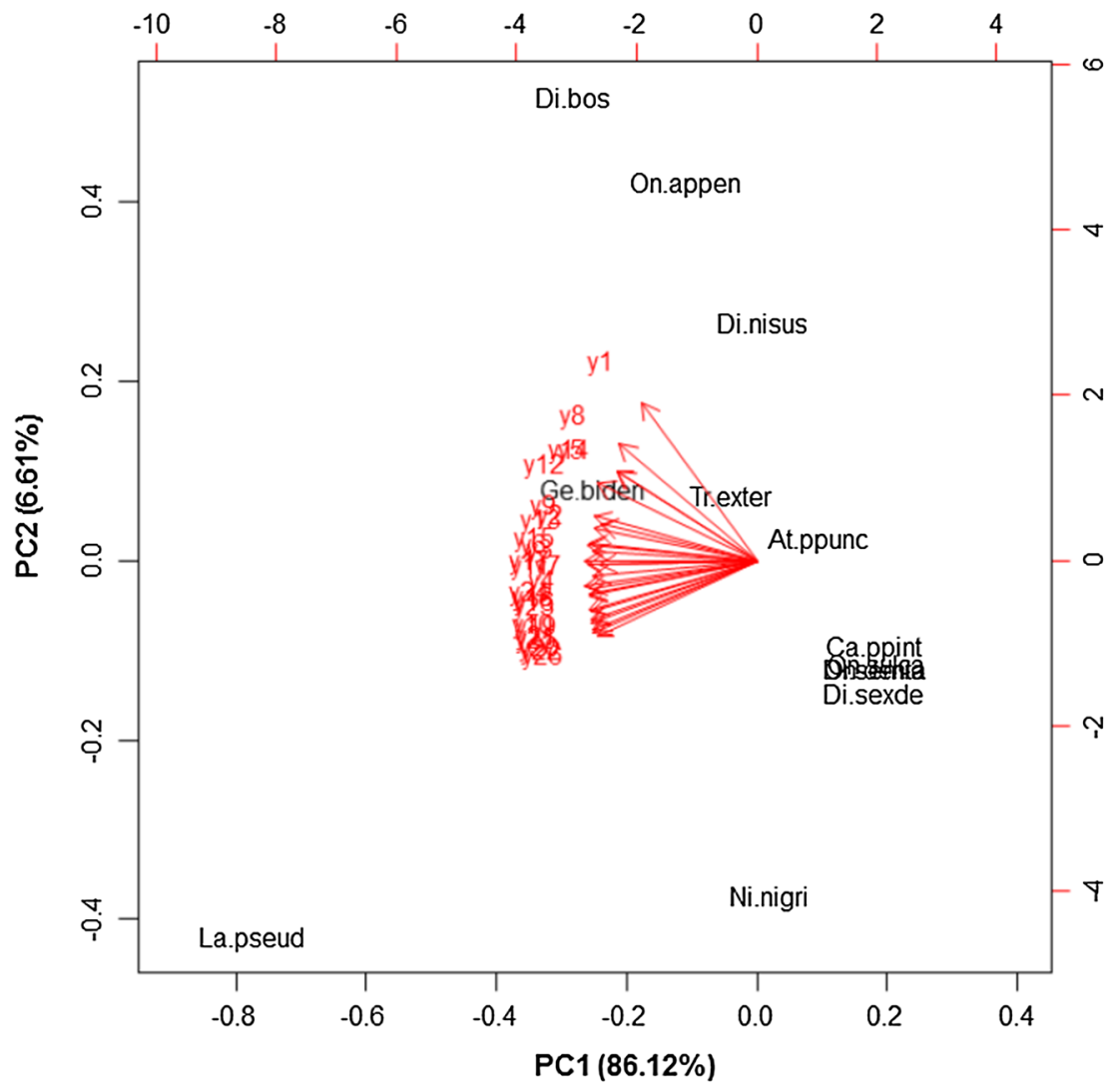

(B)

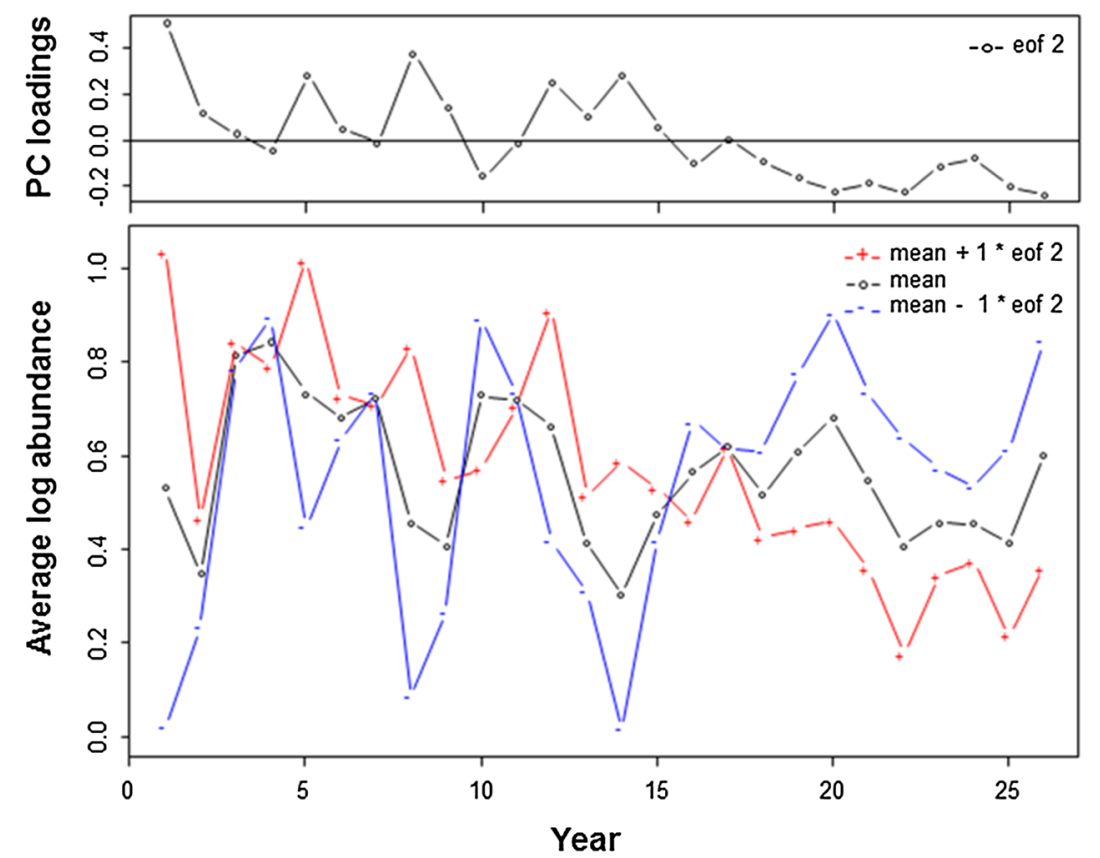


suggesting that the species that were more abundant before the invasion became less abundant afterward, and vice versa.

Based on the patterns described above, the years were grouped into three "periods" related to the invasion: before invasion (BI), comprising years 1-4 (1989-1993); after invasion I (AI-I), years 5-14 (1993-2003); and after invasion II (AI-II), which consisted of the remaining 12 years. The LDA confirmed the existence of a clear discrimination between the three periods, showing that the abundance of the native species was impacted by the invasion (Fig. 4). The differences were significant by the MANOVA test $\left(\mathrm{F}_{1,24}=11.03, p<0.001\right)$.

The RDA results were significant for the regression model $\left(\mathrm{F}_{1,19}=3.93, p=0.001\right)$ and the first three canonical axes (RDA1: $\mathrm{F}_{1,19}=14.17, p=0.001$; RDA2: $\mathrm{F}_{1,19}=4.00, p=0.002 ;$ RDA3: $\mathrm{F}_{1,19}=3.30$, $p=0.003$ ), which captured $42 \%$ of the variation in abundance. Forward-selection revealed that the abundance of the analyzed species was significantly affected by the years after invasion (year), D. gazella abundance (D.gaz), relative humidity (RH) and average minimum air temperature (aTmin) (Fig. 5). Labarrus pseudolividus and $N$. nigrita were positively correlated with year and negatively with aTmin. Five species were negatively correlated with D.gaz while three were positively correlated. Only three species showed negative correlation with $\mathrm{RH}$; the others were not affected by this explanatory variable (Fig. 5).

Given that the PCA and FDA results for all native dung beetle species showed that species with different nesting behaviors had different responses (Fig. 3), the same multivariate analyses were performed separately for the tunneler and dweller species, in order to understand how the abundance of each functional group was impacted.

Impact of D. gazella on native tunneler species

The abundance of most tunneler species decreased sharply following the invasion of D. gazella, which continued over time (Fig. 1). However, the PCA results indicated that apparently two species, D. bos and $D$. sexdentatus, increased in abundance after the invasion. Years one to four clustered together, and apart from the remaining years (Appendix S2: Fig. S3A).
Fig. 4 Bi-plot from the linear discriminant analysis (LDA) on the periods with varying native dung beetle species abundance due to the D. gazella invasion. The horizontal and vertical axes on each panel represent the first and second LDA directions, respectively. The arrows depict the loadings of the 13 most abundant species, and the orientation and length indicate the role of the abundance of each species in relation to the LDA directions and the different periods. The inset shows the first and second LDA eigenvalues (discriminatory importance of the corresponding LDA directions). See Appendix S1: Table S2 for abbreviations

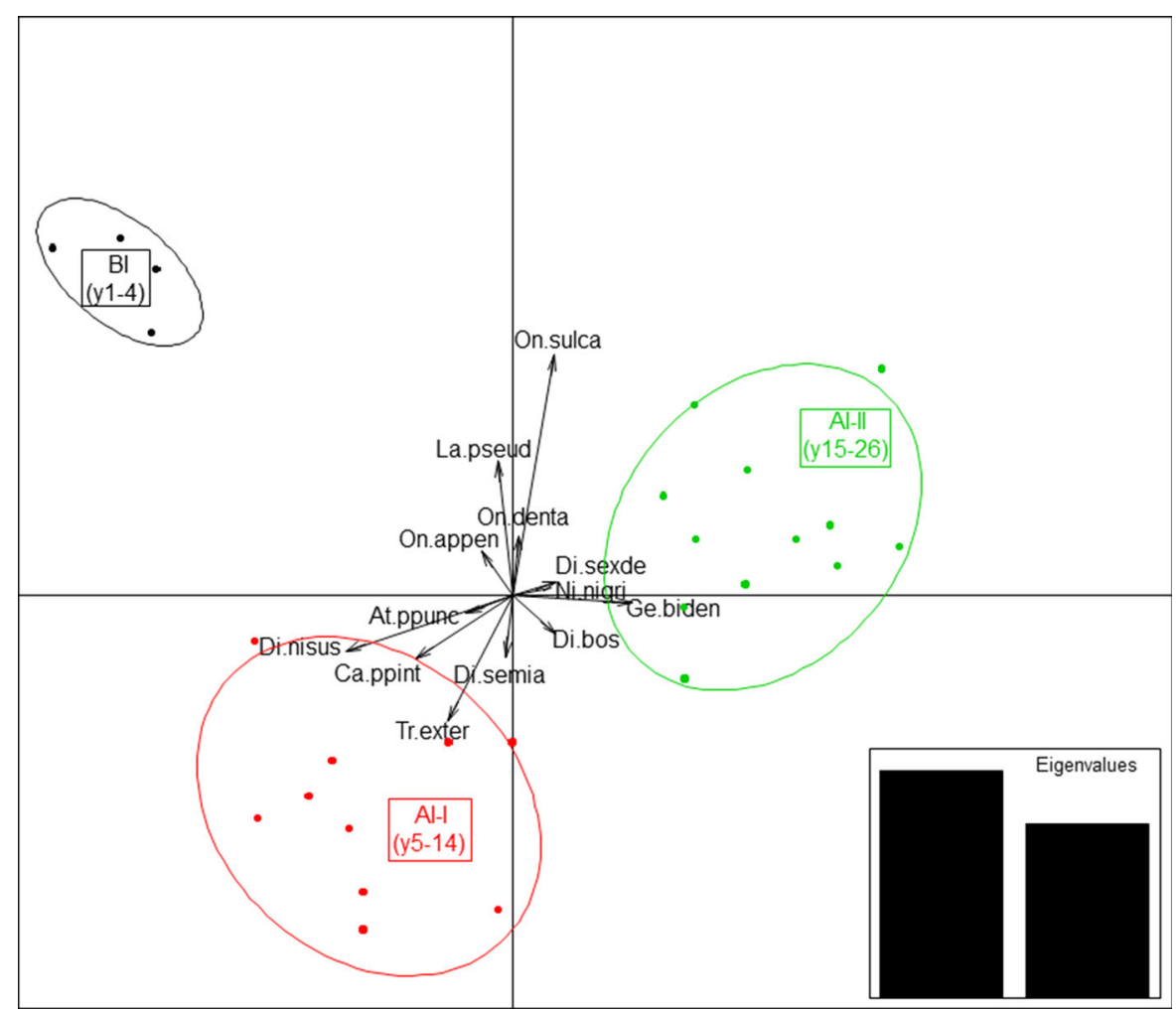


Fig. 5 Correlation tri-plot from the redundancy analysis (RDA) on the yearly abundance of native dung beetle species, showing the ordination of species abundance (response variables), years (objects) and the significant explanatory variables years since the invasion by $D$. gazella (year), abundance of D. gazella (D.gaz), relative humidity $(\mathrm{RH})$ and average minimum air temperature (aTmin). See Appendix S1: Table S2 for abbreviations

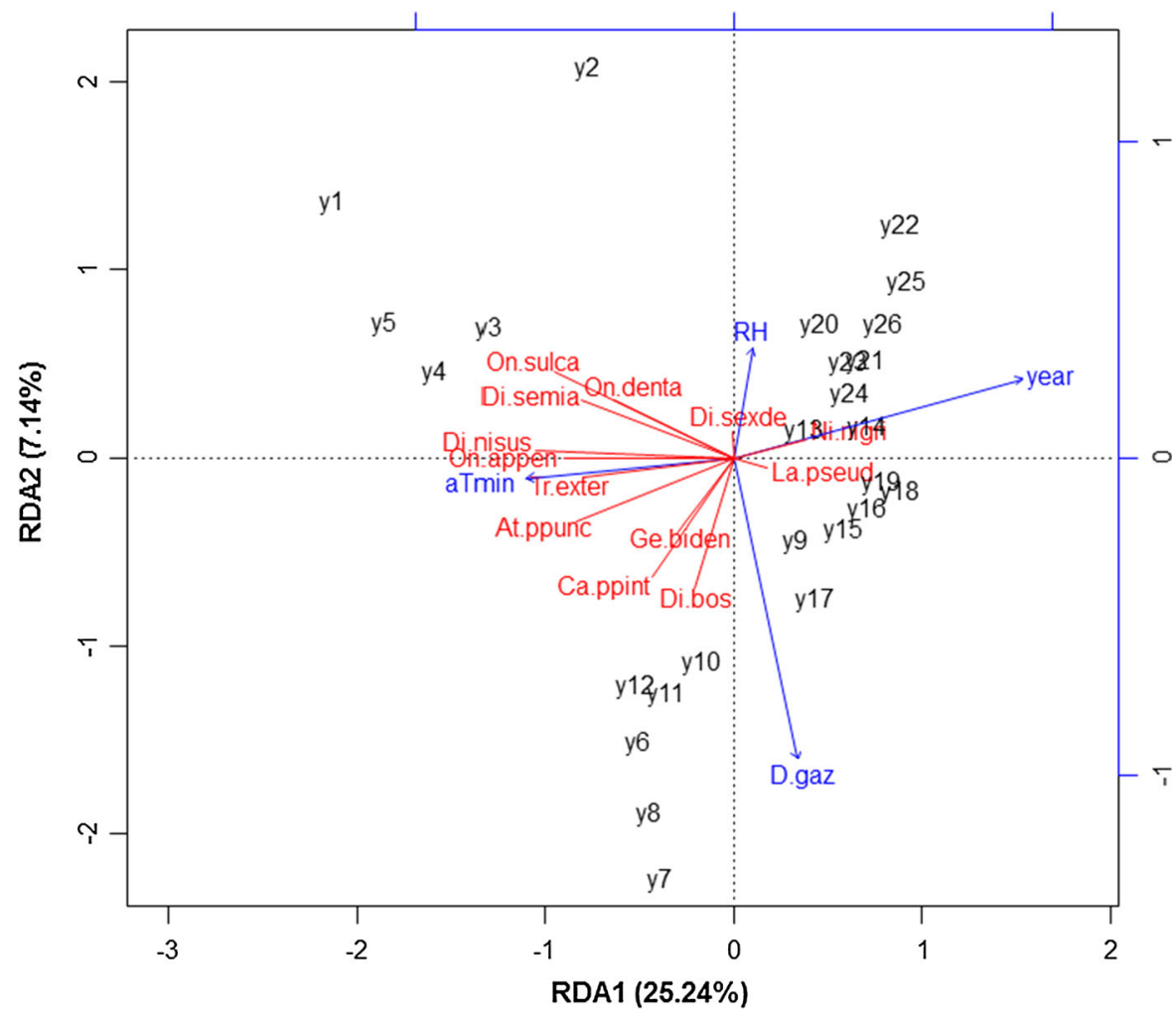

The FDA of the abundance of native tunneler species showed that the post-invasion dynamics were distinct from the dynamics observed for the all-species analysis despite the occurrence of an inversion in species prevalence. The first difference was that, contrary to the dynamics for the all-species analysis, the abundance of tunneler species decreased over all years, with no trend toward an increase. A second difference occurred in the duration of the BI period: for the tunneler species it corresponded to the years 1-5 (1989-1994), and not year 4. A third difference was the inversion, which was observed earlier, in year 13 (2001-2002), and not in year 15. Therefore, AFI-II for tunneler species included the years 13-26 (2001-2015). The last difference was that tunneler species continued to show a tendency to decrease in abundance in AFI-II (Appendix S2: Fig. S3B).

Both the LDA biplot and the MANOVA confirmed significant differences in the abundance of the species among the periods $\left(\mathrm{F}_{1,24}=31.93, p<0.001\right)$. Discrimination between periods was similar to the allspecies analysis, with three distinct periods discriminated (Appendix S2: Fig. S4). Species were discriminated into four groups, one including species that were positively impacted in the first period following the invasion (period AI-I), another including species that increased in abundance during period AI-II, a third group including species that decreased sharply in abundance in period AI-I, and the fourth with the ones that decreased in abundance during period AI-II (Appendix S2: Fig. S4).

The regression model $\left(\mathrm{F}_{6,19}=4.14, p=0.001\right)$ and the first three RDA axes were statistically significant (RDA1: $\quad \mathrm{F}_{1,19}=20.21, \quad p=0.001$; $\mathrm{F}_{1,19}=6.29, \quad p=0.001 ; \quad$ and $\quad \mathrm{F}_{1,19}=2.8$, $p=0.013$, respectively), explaining $50 \%$ of the variation in abundance. The results indicated that year since invasion, D.gaz and rainfall were significant explanatory variables. As displayed in the triplot, the differences varied within species (Appendix S2: Fig. S5). The abundances of D. bos and $C$. nr. pinotoides were positively correlated with the exotic species and negatively with year, and both species had either a weak or no correlation with rainfall. Ateuchus nr. puncticollis abundance correlated negatively only with year. The abundance of D. nisus and $O$. appendiculatus was negatively correleted with year and rainfall, and had no correlation with D. gazella. 
Ontherus sulcator, O. dentatus and $D$. sexdentatus had their abundances negatively correlated with $D$. gazella and rainfall, without showing correlation with year (Appendix S2: Fig. S5).

Impact of D. gazella on dweller species

After the invasion, there was not a distinct decrease in their abundance as observed on the tunnelers, and since year 15 (2004-2005) their abundance has been increasing. These species were able to rebound more rapidly than tunnelers following the decrease in abundance of D. gazella (Fig. 1).

The PCA results showed that among the four selected dweller species, $G$. bidens and $T$. externepunctatum decreased in abundance, whereas L. pseudolividus and N. nigrita increased following the invasion (Appendix S2: Fig. S6A). The periods were identical to the all-species FDA (Appendix S2: Fig. S6B). The MANOVA results indicated a significant difference in the abundance between periods, but only periods $\mathrm{BI}$ and $\mathrm{AI}-\mathrm{II}$ differed from each other $\left(\mathrm{F}_{1,24}=6.35, p<0.001 ;\right.$ Appendix S2: Fig. S7).

The RDA analysis captured $22 \%$ of the variation in abundance of the dweller species. The analysis with regression model $\left(\mathrm{F}_{6,19}=2.7, p=0.01\right)$, RDA1 $\left(\mathrm{F}_{1,21}=8.95, p=0.001\right)$ and RDA $2\left(\mathrm{~F}_{1,21}=4.4\right.$, $p=0.023)$ were all significant. The abundance of $G$. bidens and T. externepunctatum species showed weak correlation with the two significant explanatory variables, year (negatively) and RH (positively). Labarrus pseudolividus and $N$. nigrita had their abundances positively correlated with both variables, year and $\mathrm{RH}$ (Appendix S2: Fig. S8).

\section{Discussion}

Our results showed that the exotic tunneler dung beetle species $D$. gazella was able to rapidly establish in the study area, impacting negatively the abundance of the majority of the native species. Although the nesting behavior influenced the native species response, both dweller and tunneler communities decreased in abundance following the invasion, suggesting that the increase of $D$. gazella's population affected all species equally during that years. We observed three periods associated with the invasion. The period BI was totally different from the other two, AI-I and AI-II, suggesting the assembly of a new community after the invasion. Results from all-native species analyses showed that after 10 years of decreasing abundance (AI-II), the population size of the community rebound and a change in species prevalence occurred. The inversion in species dominance in the period AI-II was observed for both dweller and tunneler dung beetle communities. However, only dweller species were able to rebound in abundance. Population size of the tunneler community has been continuously decreasing since year 6 (1994-1995). The same tendency has been observed for the exotic species, which decreased sharply in abundance after a distinct peak of 2 years following its first record in the area (Fig. 2). Since year 16 (2004-2005), dwellers became the most abundant species, overcoming D. gazella and native tunnelers. RDA supported that $D$. gazella invasion influenced the abundance of the native species, as both year since invasion and abundance of the exotic species were significant explanatory variable for all cenarios, except for dweller species.

Before the invasion by $D$. gazella, the local community was characterized by similar numbers of species of tunnelers and dwellers; no rollers were associated with cow dung pads, and dwellers were the most abundant species (Flechtmann et al. 1995a, b, e). This general pattern was observed in our study, and was inverted only during AI-I, leading to the dominance of tunneler species (Fig. 1) in relation to dwellers in that period, restoring the initial relation among dwellers and tunnelers in AI-II. The dominance of small-bodied species in pasture areas as observed in our results was also observed in other studies (Scheffler 2005; Nichols et al. 2007).

Decrease in population size and species diversity are the most common outcomes of invasion by insects (McGeoch et al. 2015). We showed that both decreases occurred in the study area following the invasion by $D$. gazella. Because the majority of native species decreased in abundance and only a few species, especially Labarrus pseudolividus, were able to recover their population abundance, the lower diversity in AI-II compared to BI is the consequence of few species dominating the area. Another important change to contribute to that was the inversion in the prevalence of species observed in AI-II (Fig. 3b). Since Hill's diversity number $N_{1}$ is a method that unifies Shannon's index and evenness (Hill 1973), the lower values are a consequence of the smaller number 
of highly abundant species (dwellers) and a majority of less-abundant species (tunnelers) after the invasion, as opposed to the period before it (Appendix S1: Table S1).

Invasion by exotic insect species usually may cause species extinctions (Kenis et al. 2009; McGeoch et al. 2015). Although some species cited in this study were never collected again after the invasion (Appendix S1: Table S1), this could have happened due to an expressive drop in abundance, not extinction by itself.

The recognition of three distinct periods during the process of invasion shows the importance and necessity of long-term studies for a correct evaluation of the impacts of any invasive species. Each period was characterized by a unique dynamic (Fig. 2), and only continuous and regularly-spaced data collections made it possible to determine them. These results also highlight the importance of regular samplings for a correct evaluation of the impacts of a biological invasion (Wilson et al. 2004; McCarthy et al. 2006; Stricker et al. 2015).

There are several abiotic and biotic barriers that an exotic species must overcome in order to establish in a new environment (Blackburn et al. 2011; Zenni et al. 2017) and the pathway to an invasion is important when evaluating the dynamics of an exotic species (Liebhold et al. 2016).

The successful invasion and establishment of D. gazella was possible conceivably because of the suitable environmental conditions in the invaded area (Duncan 2016), the ability of D. gazella to rapidly acquire resources (Young 2007), and its high fecundity rate and short life cycle (Blume and Aga 1975). In addition, dung was highly available, as hundreds heads of cattle were present in the area every year (Appendix S2: Fig. S9). These characteristics enabled D. gazella to outcompete native dung beetles and increase its population very rapidly in only 2 years. However, a common consequence of such rapid population growth was seen in the sharp decrease of D. gazella abundance after its peak, which often occurs in biological invasions (Hengeveld 1989), as seen in Fig. 2. This decrease might have been resulted from intense intraspecific competition in D. gazella. High densities of conspecifics result in fewer and smaller offspring. Smaller adults bury dung slowly, increasing their feeding time and exposing them to more intense intraand interspecific competition. Thus, smaller adults utilize less of the resource and provision their larvae with less-nutritious food sources. As a consequence, their offspring are smaller and lay fewer eggs, resulting in decreased abundance (Lee and Peng 1981, 1982). Once low numbers are reached, interspecific competition and other ecological forces as predation, parasitism and diseases are likely to become more important, which could explain the lack of high numbers in $D$. gazella after the post-invasion period and its continuous decrease in abundance.

Exotic species are subjected to genetic inbreeding depression, which can limit their abundance (Dlugosch and Parker 2008). This may also have affected the dynamics of the population of D. gazella (Fig. 2) because the genetic diversity of this species is considered to be low in Brazil (Martins and Contel 2001).

Competition in dung pads can be fierce (Hanski and Cambefort 1991a). In general, species that share the same resource require a higher level of intraspecific than interspecific competition in order to coexist (Chesson 2000), which requires that these species partition the resource to some extent (Chesson 1991). The invasion by $D$. gazella disrupted this balance in the native community, leading to higher interspecific competition, a situation that could have led to the competitive exclusion of inferior competitors and a decrease in the abundance of species that shared the same ecological niche (Atkinson and Shorrocks 1981; Shorrocks et al. 1984; Ives 1988a, b; Hanski 1991). Competition with native species is a well-known mechanism by which exotic insect species impacts local communities (Rowles and O'Dowd 2007; Kenis et al. 2009; Brown et al. 2011; Roy and Brown 2015).

Body size is an important characteristic when the concern is dung beetle community competition. Bigger species (usually rollers and tunnelers) tend to be superior competitors than smaller ones (dwellers) (Hanski and Cambefort 1991a). Therefore, it was expected that the impacts of the invasion by $D$. gazella would be harsh in those species of the same size or smaller than the exotic. However, our results did not support this hypothesis. A previous study at the same location showed that Dichotomius species were the largest species, followed by Ontherus, while dwellers were the smallest ones (Flechtmann et al. 1995a). Following the same methodology, D. gazella would be classified as a medium-sized species. The species more negatively impacted, $O$. appendiculatus, indeed has the same size of D. gazella. However, regardless of 
body size, all species were negatively affected during AI-I. Moreover, either species bigger (D. bos and D. sexdentatus) and smaller (L. pseudolividus and $N$. nigrita) than $D$. gazella were positively affected. Therefore, body size does not seem to have influenced the species response.

Niche partitioning is another important ecological characteristic that can affect the outcome of dung beetle species competition (Giller and Doube 1994). The importance of temporal niche partitioning with a superior competitor is evident in the response of the native species to the invasion. Digitonthophagus gazella initiates its activity early after the first rains (de Oca and Halffter 1995). All the native species that were negatively impacted by $D$. gazella have a peak in their annual activities early in the rainy season (Flechtmann et al. 1995b, e), whether they are tunnelers or dwellers. In contrast, native species that reach their peak activity later in the year, such as $D$. bos and most of the dweller species (Flechtmann et al. $1995 \mathrm{~b}, \mathrm{e})$, increased in abundance despite the presence of the exotic species, presumably because, due to the negative impacts on the other native species, interspecific competition in the community in general was lower at that time.

The dweller species were able to rebound in abundance faster than the tunnelers as D. gazella decreased in number over the years (Fig. 1). Dwellers, while having a late active peak, also remain active for a longer period when neither tunnelers nor D. gazella are active on cow pads (Flechtmann et al. 1995b, e). Furthermore, dweller species are spatially aggregated (Hutton and Giller 2004), require a smaller amount of resource to survive and reproduce (Holter 1982), have a higher fecundity rate (Holter 1979) and a shorter life cycle (Verdú and Galante 1997) than tunneler species. All these characteristics likely enabled the dweller species to rebound rapidly in numbers as the exotic and native tunneler species decreased in abundance. Therefore, D. gazella did not directly influence the response of the dweller species, which explains the lack of significance of D.gaz among the explanatory variables tested (Appendix S2: Fig. S8). Neither the changes in environmental conditions nor the invasion made it possible for dweller species to increase, but rather the decrease in abundance of other dung beetle species caused by the invasion of D. gazella.

A behavioral characteristic of dweller species might have positively influenced its rebound in abundance while affecting negatively the abundance of tunneler species, including D. gazella. More common in tropical and subtropical regions as a consequence of the intense competition (Hanski and Cambefort 1991a), kleptoparasitic behavior has been observed in some small tunneler and dweller species, like L. pseudolividus (Howden 1955; Hammond 1976; Rougon and Rougon 1980; Klemperer 1980; Brussaard 1987; Martín-Piera and Lobo 1993). By using the brood ball of superior competitors to their own feeding and reproduction, inferior competitors can coexist with these species while negatively affecting the larvae of the other species, by reducing the amount of available resources or by direct killing competitor larvae (Rougon and Rougon 1980; Hammond 1976). Because of the high numbers L. pseudolividus, it is probable that more of their eggs, larvae and adults have been unintentionally buried by tunneler species, leading to a negative effect on their population while enabling L. pseudolividus to increase its population size.

The impacts of exotic species on ecosystem services is of great concern due to their ecological and financial importance (Vilà et al. 2010; Simberloff 2014; Vilà and Hulme 2017). Our results suggest that the invasion by $D$. gazella may have led to a decrease in the ecosytem functions provided by native dung beetles, with possible economic impacts. Tunneler dung beetles bury the largest amount of excrement among all dung beetles (Hanski and Cambefort 1991b), and body size is positively correlated with dung burying (Giller and Doube 1989; Dangles et al. 2012). In our study area, the large- and medium-sized tunneler species are responsible for dung-pad burial, and dwellers are not correlated with dung-pad removal (Flechtmann et al. 1995a). Several recent studies have suggested that ecosystem services provided by dung beetles, including dung pad removal, might benefit from having several functional groups (Slade et al. 2007; Manning et al. 2016; Menéndez et al. 2016). Therefore, as the tunnelers, including the invasive species, became less abundant and the dwellers increased in number, the invasion of $D$. gazella might have led to effects opposite of those expected from its introduction: less cow dung buried, with a consequent increase in the amount of dung available for cattle pests and parasites to breed. This can still be occurring despite the high numbers of $D$. gazella because the higher the density of this dung beetle per dung pad, the 
lower the amount of dung buried (Lee and Peng 1982), an effect that was also observed on other dung beetle species (Ridsdill-Smith et al. 1982; Ridsdill-Smith 1991). This is a matter of concern, not only because of the possible increase in livestock economic losses, which are estimated to be around USD14 billion per year in Brazil (Grisi et al. 2014), but mainly because one of the main reasons for the introduction was to promote the biological control of these pests (Bianchin et al. 1992).

Climate change can be advantageous for an invasive species, but the effects of this change on native species and the native community require additional studies (Dukes and Mooney 1999; Stachowicz et al. 2002). Our analyses showed that rainfall, mean minimum air temperature, and relative humidity were significant covariates, along with the abundance of the exotic species and years since invasion. The occurrence of the El Niño-Southern Oscillation (ENSO), which affects temperature and precipitation in Brazil (Marengo et al. 1998), might influence dung beetles at the species and community levels. The oscillations in weather conditions caused by ENSO could be related to the fluctuations in the species abundance through the years, causing an increase in some years and a decrease in others. However, as different species may respond in different ways to warmer climates (Ruokolainen et al. 2009; Chen et al. 2011; Fowler and Ruokolainen 2013), further investigation is needed to predict how environmental changes influence the dynamics of the native dung beetle species.

Although only one trap was used, we believe that our results are robust due to some characteristics of our sampling methods and of the study area. Regarding the sampling method the long-term, regular data collection, which includes data for the 4 years preceding the invasion, make it possible to compare the abundance of native species before and after the invasion. In addition, the data were collected in the same place throughout the study, which allowed us to collect information on abiotic factors that could have influenced the results.

Black light flight intercept traps are not commonly employed to collect dung beetles, which is usually done with the use of dung-baited pitfall traps (Hanksi and Cambefort 1991b). Nonetheless, it is still a valid methodology (Hill 1996). Additionally, pitfall trap collections are though influenced by a number of variables, such as size and source of dung (Gill 1991;
Errouissi et al. 2004; Filgueiras et al. 2009) and smell of decaying trapped insects (Flechtmann et al. 2009), to name a few. Such variables do not interfere with the efficiency of the attractant (black light) in light traps though. Another characteristic is that, although the city of Selvíria, adjacent to the collecting site, could have affect the trapping because of light pollution (Rich and Longcore 2006), Selvíria did not expand in size over the years (Flechtmann pers. observ.).

One factor in the study area that could have influenced the dung beetle population might be depletion and/or variation of the resource, i.e., dung. However, after livestock were introduced into the farm in 1984, the number of cattle varied very little over the years and averaged 800 head/year, half of them calves $(<36$ months old) and the other half adults ( $>36$ months old), producing a constant and sufficient amount of dung for dung beetle development (Appendix S2: Fig. S9). Also, it has been suggested that fertilizers can influence dung beetle populations (Holm and Wallace 1987). Indeed, some elements in fertilizers, such as nitrogen and potassium, can be toxic to insects (Nation 2015). However, on the farm only a few areas have occasionally received lime and phosphate over the years, and only once since the pasture establishment. Hence, it is unlikely that any soil application could have influenced changes in the dung beetle community.

As far as we can tell, we have here a unique set of features, not paralleled by any other studies found in the literature regarding any studies on the impact of an animal invader species, let alone an insect, which allow one to correctly evaluate the effect of an exotic species on the native fauna.

\section{Conclusion}

Our results show that the invasion by $D$. gazella was detrimental to the native dung beetle community, specifically for species that overlap with D. gazella in both nesting behavior and phenology.

Because of the decrease in diversity and the changes in abundance and dominance of the native dung beetle species, the invasion by $D$. gazella led to a new community in which dwellers are the most abundant group of species, with a tendency to maintain high numbers, whereas tunneler species abundance has been decreasing since the invasion 
and shows no sign of recovery from the negative effects of the invasion.

The consequences of the invasion of D. gazella are the more worrisome, as it is now present in all states of Brazil and has been recorded in almost all countries in Central and South America, from Mexico to Uruguay (Rivera and Wolff 2007; Vidaurre et al. 2008; Alvarez Bohle et al. 2009; Noriega et al. 2010, 2017). Based on our results, D. gazella is a threat to the native dung beetle fauna of all these countries and could cause serious damage to the local ecosystems.

Acknowledgements CAHF would like to thank his UNESP students Alexsander Seleguini, Angelo Luiz Tadeu Ottati, Cid Tacaoca Muraishi, Fabiana Oikawa, and Sérgio Roberto Rodrigues, who worked on the identification of the species over the years, all local Farm employees for making possible the collections throughout all these years, with special thanks to Moacir José Ruela, and the Fundação de Amparo à Pesquisa do Estado de São Paulo (FAPESP, Process No. 99/08312-2) for financial support. WMF extends thanks to the Coordenação de Aperfeiçoamento de Pessoal de Nível Superior (CAPES) for the Ph.D. grant, and to Damie Pak, Catherine Herzog and Rafael Zenni for their thoughtful reviews.

\section{References}

Alvarez Bohle MC, Damborsky MP, Bar ME, Ocampo FC (2009) Records and distribution of the Afro Asian species Digitonthophagus gazella (Coleoptera: Scarabaeidae: Scarabaeinae) in Argentina. Rev la Soc Entomol Argentina 68:373-376

Atkinson WD, Shorrocks B (1981) Competition on a divided and ephemeral resource: a simulation model. J Anim Ecol 50:461-471. https://doi.org/10.2307/4067

Barbero E, Lopez-Guerrero Y (1992) Some considerations on the dispersal power of Digitonthophagus gazella (Fabricius, 1787) in the New World (Coleoptera, Scarabaeidae, Scarabaeinae). Trop Zool 5:115-120. https://doi.org/10. 1080/03946975.1992.10539184

Bertone M, Green J, Washburn S et al (2005) Seasonal activity and species composition of dung beetles (Coleoptera: Scarabaeidae and Geotrupidae) inhabiting cattle pastures in North Carolina. Ann Entomol Soc Am 98:309-321. https://doi.org/10.1603/0013-8746(2005)098[0309: SAASCO]2.0.CO;2

Bianchin I, Honer MR, Gomes A (1992) Controle integrado da mosca-dos-chifres na região Centro-Oeste. A Hora Vet 11:43-46

Blackburn TM, Pyšek P, Bacher S et al (2011) A proposed unified framework for biological invasions. Trends Ecol Evol 26:333-339. https://doi.org/10.1016/j.tree.2011.03. 023

Blossey BB (1999) Before, during and after: the need for longterm monitoring in invasive plant species management.
Biol Invasions 1:301-311. https://doi.org/10.1023/a: 1010084724526

Blume RR, Aga A (1975) Onthophagus gazella: mass rearing and laboratory biology. Environ Entomol 4:735736. https://doi.org/10.1093/ee/4.5.735

Blume RR, Aga A (1978) Onthophagus gazella F: progress of experimental release in south Texas. Folia Entomol Mex 39-40:190-191

Borcard D, Gillet F, Legendre P (2011) Numerical ecology with R, 1st edn. Springer, New York. https://doi.org/10.1007/ 978-1-4419-7976-6

Bornemissza GF (1960) Could dung eating insects improve our pastures? J Aust Inst Agric Sci 26:54-56

Bornemissza GF (1970) Insectary studies on the control of dung breeding flies by the activity of dung beetle, Onthophagus gazella (Coleoptera: Scarabaeinae). Aust J Entomol 9:31-41. https://doi.org/10.1111/j.1440-6055.1970.tb00767.x

Bornemissza GF (1979) The Australian dung beetle research unit in Pretoria. S Afr J Sci 75:257-260

Brown PMJ, Frost R, Doberski J et al (2011) Decline in native ladybirds in response to the arrival of Harmonia axyridis: early evidence from England. Ecol Entomol 36:231-240. https://doi.org/10.1111/j.1365-2311.2011.01264.x

Brussaard L (1987) Kleptocopry of Aphodius coenosus (Coleoptera, Aphodiidae) in nests of Typhaeus typhoeus (Cleoptera, Geotrupidae) and its effect on soil morphology. Biol Fertil Soils 3-3:117-119. https://doi.org/10.1007/ BF00260591

Cambefort Y (1984) Etude écologique des Coléoptères Scarabaeidae de Côte d'Ivoire. Ecole Normale Supérieure, vol 3, pp $294+12$. Travaux des chercheurs de la station de Lamto, 2-7288-0099-5 <hal-01374057>

Chen IC, Hill JK, Ohlemueller R et al (2011) Rapid range shifts of species associated with high levels of climate warming. Science 333(80):1024-1026. https://doi.org/10.1126/ science. 1206432

Chesson P (1991) A need for niches? Trends Ecol Evol 6:26-28. https://doi.org/10.1016/0169-5347(91)90144-m

Chesson P (2000) Mechanisms of maintenance of species diversity. Annu Rev Ecol Syst 31:343-366. https://doi.org/ 10.1146/annurev.ecolsys.31.1.343

Crooks JA (2005) Lag times and exotic species: the ecology and management of biological invasions in slow-motion. Ecoscience 12:316-329. https://doi.org/10.2980/i11956860-12-3-316.1

Dangles O, Carpio C, Woodward G (2012) Size-dependent species removal impairs ecosystem functioning in a largescale tropical field experiment. Ecology 93:2615-2625

Davis ALV (1996) Community organization of dung beetles (Coleoptera: Scarabaeidae): differences in body size and functional group structure between habitats. Afr J Ecol 34:258-275. https://doi.org/10.1111/j.1365-2028.1996. tb00621.x

de Oca EM, Halffter G (1995) Daily and seasonal activities of a guild of the coprophagous, burrowing beetle (Coleoptera Scarabaeidae Scarabaeinae) in tropical grassland. Trop Zool 8:159-180. https://doi.org/10.1080/03946975.1995. 10539277

de Oca EM, Halffter G (1998) Invasion of Mexico by two dung beetles previously introduced into the United States. Stud 
Neotrop Fauna Environ 33:37-45. https://doi.org/10.1076/ snfe.33.1.37.2174

Dlugosch KM, Parker IM (2008) Founding events in species invasions: genetic variation, adaptive evolution, and the role of multiple introductions. Mol Ecol 17:431-449. https://doi.org/10.1111/j.1365-294X.2007.03538.x

Drake JM (2004) Allee effects and the risk of biological invasion. Risk Anal 24:795-802. https://doi.org/10.1111/j. 0272-4332.2004.00479.x

Dray S, Legendre P, Blanchet G (2013) packfor: forward selection with permutation $\mathrm{R}$ package version 00-8/r109. https://rdrr.io/rforge/packfor/

Dukes JS, Mooney HA (1999) Does global change increase the success of biological invaders? Trends Ecol Evol 14: 135-139. https://doi.org/10.1016/s0169-5347(98)01554-7

Duncan RP (2016) How propagule size and environmental suitability jointly determine establishment success: a test using dung beetle introductions. Biol Invasions 18:985-996. https://doi.org/10.1007/s10530-016-1083-8

Ellison AM (2010) Partitioning diversity. Ecology 91:1962-1963. https://doi.org/10.1890/09-1692.1

Errouissi F, Haloti S, Jay-robert P et al (2004) Effects of the attractiveness for dung beetles of dung pat origin and size along a climatic gradient. Environ Entomol 33:45-53. https://doi.org/10.1603/0046-225X-33.1.45

Filgueiras BKC, Liberal CN, Aguiar CDM et al (2009) Attractivity of omnivore, carnivore and herbivore mammalian dung to Scarabaeinae (Coleoptera, Scarabaeidae) in a tropical Atlantic rainforest remnant. Rev Bras Entomol 53:422-427. https://doi.org/10.1590/S0085-5626200900 0300017

Flechtmann CAH, Rodrigues SR, do Couto HTZ (1995a) Controle biológico da mosca-dos-chifres (Haematobia irritans irritans) em Selvíria, Mato Grosso do Sul. 2. Ação de insetos fimícolas em massas fecais no campo. Rev Bras Entomol 39:237-247

Flechtmann CAH, Rodrigues SR, do Couto HTZ (1995b) Controle biológico da mosca-dos-chifres (Haematobia irritans irritans) em Selvíria, Mato Grosso do Sul. 4. Comparação entre métodos de coleta de besouros coprófagos (Scarabaeidae). Rev Bras Entomol 39:259-276

Flechtmann CAH, Rodrigues SR, Gaspareto CL, do Couto HTZ (1995c) Controle biológico da mosca-dos-chifres (Haematobia irritans irritans) em Selvíria, Mato Grosso do Sul. 5. Seleção de besouros coprófagos. Rev Bras Entomol 39:277-286

Flechtmann CAH, Rodrigues SR, Seno MCZ (1995d) Controle biológico da mosca-dos-chifres (Haematobia irritans irritans) em Selvíria, Mato Grosso do Sul. 1. Metodologia de estudo e seleção de fauna fimícola de insetos. Rev Bras Entomol 39:1-11

Flechtmann CAH, Rodrigues SR, Seno MCZ (1995e) Controle biológico da mosca-dos-chifres (Haematobia irritans irritans) em Selvíria, Mato Grosso do Sul. 3. Levantamento de espécies fimícolas associadas à mosca. Rev Bras Entomol 39:249-258

Flechtmann CAH, Tabet VG, Quintero I (2009) Influence of carrion smell and rebaiting time on the efficiency of pitfall traps to dung beetle sampling. Entomol Exp Appl 132:211-217. https://doi.org/10.1111/j.1570-7458.2009. 00885.x
Fowler MS, Ruokolainen L (2013) Colonization, covariance and colour: environmental and ecological drivers of diversitystability relationships. J Theor Biol 324:32-41. https://doi. org/10.1016/j.jtbi.2013.01.016

Génier F, Moretto P (2017) Digitonthophagus Balthasar, 1959: taxonomy, systematics, and morphological phylogeny of the genus revealing an African species complex (Coleoptera: Scarabaeidae: Scarabaeinae). Zootaxa 4248:110. https://doi.org/10.11646/zootaxa.4248.1.1

Gill BD (1991) Dung beetles in Tropical American forests. In: Hanski I, Cambefort Y (eds) Dung beetle ecology, 1st edn. Princeton University Press, Princeton, pp 211-229

Giller PS, Doube BM (1989) Experimental analysis of inter- and intraspecific competition in dung beetle communities. J Anim Ecol 58:129-142. https://doi.org/10.2307/4990

Giller PS, Doube BM (1994) Spatial and temporal co-occurrence of competitors in Southern African dung beetle communities. J Anim Ecol 63:629-643. https://doi.org/10. 2307/5229

Grisi L, Leite RC, de Souza Martins JR et al (2014) Reassessment of the potential economic impact of cattle parasites in Brazil. Rev Bras Parasitol Vet 23:150-156. https://doi.org/ 10.1590/s1984-29612014042

Gutierrez J, Macqueen A, Brun LO (1988) Essais d'introduction de quatre espèces de bousiers Scarabaeinae en Nouvelle Calédonie et au Vanuatu. Acta Oecol Oecol Appl 9:39-53

Halffter G, Edmonds WD (1982) The nesting behavior of dung beetles (Scarabaeinae): an ecological and evolutive approach, 1st edn. Instituto de Ecología, México

Halffter G, Matthews EG (1966) The natural history of dung beetles of the subfamily Scarabaeinae (Coleoptera. Scarabaeidae). A monograph. Folia Entomol Mex 12/14:1-32

Halffter G, Favila ME, Halffter V (1992) A comparative study of the structure of the scarab guild in Mexican tropical rain forests and derived ecosystems. Folia Entomol Mex 84:131-156

Hammond PM (1976) Kleptoparasitic behaviour of Onthophagus suturalis Peringuey (Coleoptera: Scarabaeidae) and other dung-beetles. Coleopt Bull 30:245-249

Hanski I (1991) The dung insect community. In: Hanski I, Cambefort Y (eds) Dung beetle ecology, 1st edn. Princeton University Press, Princeton, pp 5-21

Hanski I, Cambefort Y (1991a) Competition in dung beetles. In: Hanski I, Cambefort Y (eds) Dung beetle ecology, 1st edn. Princeton University Press, Princeton, pp 305-329

Hanski I, Cambefort Y (1991b) Dung beetle ecology, 1st edn. Princeton University Press, Princeton

Hengeveld R (1989) Dynamics of Biological Invasions, 1st edn. Springer, Netherlands, Dordrecht

Hill MO (1973) Diversity and evenness: a unifying notation and its consequences. Ecology 54:427-432. https://doi.org/10. 2307/1934352

Hill CO (1996) Habitat specificity and food preferences of an assemblage of tropical Australian dung beetles. J Trop Ecol 12:449-446. http://www.jstor.org/stable/2560300

Holm E, Wallace MMH (1987) The influence of superphosphate on the establishment of introduced dung beetles in Southeastern Australia. J Aust Inst Agric Sci 53:202-204

Holter P (1979) Abundance and reproductive strategy of the dung beetle Aphodius rufipes (L.) (Scarabaeidae). Ecol 
Entomol 4:317-326. https://doi.org/10.1111/j.1365-2311. 1979.tb00591.x

Holter P (1982) Resource utilization and local coexistence in a guild of scarabaeid dung beetles (Aphodius spp.). Oikos 39:213. https://doi.org/10.2307/3544488

Howden HF (1955) Cases of interspecific "parasitism" in Scarabaeidae (Coleoptera). J Tenn Acad Sci 30:64-66

Howden HF, Scholtz CH (1986) Changes in a Texas dung beetle community between 1975 and 1985 (Coleoptera, Scarabaeidae, Scarabaeinae). Coleopt Bull 40:313-316

Hutton SA, Giller PS (2004) Intra- and interspecific aggregation of north temperate dung beetles on standardised and natural dung pads: the influence of spatial scale. Ecol Entomol 29:594-605. https://doi.org/10.1111/j.0307-6946.2004. 00634.x

Ives AR (1988a) Aggregation and the coexistence of competitors. Ann Zool Fennici 25:75-88

Ives AR (1988b) Covariance, coexistence and the population dynamics of two competitors using patchy resource. J Theor Biol 133:345-361. https://doi.org/10.1016/s00225193(88)80326-6

Kenis M, Auger-Rozenberg M-AA, Roques A et al (2009) Ecological effects of invasive alien insects. Biol Invasions 11:21-45. https://doi.org/10.1007/s10530-008-9318-y

Klein BC (1989) Effects of forest fragmentation on dung and carrion beetle communities in Central Amazonia. Ecology 70:1715-1725. https://doi.org/10.2307/1938106

Klemperer HG (1980) Kleptoparasitic behaviour of Aphodius rufipes (L.) larvae in nests of Geotrupes spiniger Marsh. (Coleoptera, Scarabaeidae). Ecol Entomol 5:143-151. https://doi.org/10.1111/j.1365-2311.1980.tb01135.x

Kohlmann B (1991) Dung beetles in Subtropical North America. In: Hanski I, Cambefort Y (eds) Dung beetle ecology, 1st edn. Princeton University Press, Princeton, pp 116-132

Koskela H (1979) Patterns of diel flight activity in dung-inhabiting beetles: an ecological analysis. Oikos 33:419-439. https://doi.org/10.2307/3544330

Kottek M, Grieser J, Beck C et al (2006) World map of the Köppen-Geiger climate classification updated. Meteorol Z 15:259-263. https://doi.org/10.1127/0941-2948/2006/0130

Krell F-T, Krell-Westerwalbesloh S, Weiß I et al (2003) Spatial separation of Afrotropical dung beetle guilds: a trade-off between competitive superiority and energetic constraints (Coleoptera: Scarabaeidae). Ecography (Cop) 26:210-222. https://doi.org/10.1034/j.1600-0587.2003.03278.x

Lee JM, Peng Y-S (1981) Influence of adult size of Onthophagus gazella on manure pat degradation, nest construction, and progeny size. Environ Entomol 10:626-630. https:// doi.org/10.1093/ee/10.5.626

Lee JM, Peng Y-S (1982) Influence of manure availability and nesting density on the progeny size of Onthophagus gazella. Environ Entomol 11:38-41. https://doi.org/10. 1093/ee/11.1.38

Legendre P, Legendre L (2012) Numerical ecology, 3rd edn. Elsevier, Amsterdam

Liebhold AM, Yamanaka T, Roques A et al (2016) Global compositional variation among native and non-native regional insect assemblages emphasizes the importance of pathways. Biol Invasions 18:893-905. https://doi.org/10. 1007/s10530-016-1079-4
Manning P, Slade EM, Beynon SA, Lewis OT (2016) Functionally rich dung beetle assemblages are required to provide multiple ecosystem services. Agric Ecosyst Environ 218:87-94. https://doi.org/10.1016/j.agee.2015.11.007

Marengo JA, Tomasella J, Uvo CR (1998) Trends in streamflow and rainfall in tropical South America: Amazonia, eastern Brazil, and northwestern Peru. J Geophys Res Atmos 103:1775-1783. https://doi.org/10.1029/97JD02551

Martín-Piera F, Lobo JM (1993) New data and observations on kleptoparasitic behaviour in dung beetles from temperate regions (Coleoptera: Scarabaeoidea). Acta Zool Mex 537:15-18

Martins E, Contel EPB (2001) African dung beetle Onthophagus gazella Fabricius (Coleoptera: Scarabaeidae) esterase isozymes. Braz J Biol 61:645-650. https://doi.org/10.1590/ S1519-69842001000400014

Matioli JC, Silveira Neto S (1988) Armadilhas luminosas: funcionamento e utilização. Boletim Técnico da EPAMIG 28:1-44

McCarthy JM, Hein CL, Olden JD et al (2006) Coupling longterm studies with meta-analysis to investigate impacts of non-native crayfish on zoobenthic communities. Freshw Biol 51:224-235. https://doi.org/10.1111/j.1365-2427. 2005.01485.x

McGeoch MA, Lythe MJ, Henriksen MV, McGrannachan CM (2015) Environmental impact classification for alien insects: a review of mechanisms and their biodiversity outcomes. Curr Opin Insect Sci 12:46-53. https://doi.org/ 10.1016/j.cois.2015.09.004

Menéndez R, Webb P, Orwin KH (2016) Complementarity of dung beetle species with different functional behaviours influence dung-soil carbon cycling. Soil Biol Biochem 92:142-148. https://doi.org/10.1016/j.soilbio.2015.10.004

Morrison LW (2002) Long-term impacts of an arthropod-community invasion by the imported fire ant, Solenopsis invicta. Ecology 83:2337-2345. https://doi.org/10.2307/ 3072064

Nation JL (2015) Insect physiology and biochemistry, 3rd edn. CRC Press, Boca Raton

Nichols E, Larsen T, Spector S et al (2007) Global dung beetle response to tropical forest modification and fragmentation: a quantitative literature review and meta-analysis. Biol Conserv 137:1-19. https://doi.org/10.1016/j.biocon.2007. 01.023

Noriega JA, Horgan FG, Larsen TH, Valencia G (2010) Records of an invasive dung beetle species, Digitonthophagus gazella (Fabricius, 1787) (Coleoptera: Scarabaeidae), in Peru. Acta Zool Mex Nueva Ser 26:451-456

Noriega JA, Delgado O, Blanco JI et al (2017) Introduction, establishment, and invasion of Digitonthophagus gazella (Fabricius, 1787) (Coleoptera: Scarabaeinae) in the savannas of Venezuela and Colombia. Nat Resour 8:370-381. https://doi.org/10.4236/nr.2017.85023

Oksanen, J, Blanchet FG, Kindt R et al (2015) vegan: community Ecology Package R package version 23-1. https://cran. r-project.org/web/packages/vegan/index.html

Porter SD, Savignano DA (1990) Invasion of polygine fire ants decimates native ants and disrupts arthropod community. Ecology 71:2095-2106. https://doi.org/10.2307/1938623 
R Core Team (2015) R: a language and environment for statistical computing R Foundation for Statistical Computing, Vienna, Austria. https://www.r-project.org/

Ramsay J, Silverman BW (2005) Functional data analysis, 2nd edn. Springer, New York. https://doi.org/10.1007/b98888

Rich C, Longcore T (2006) Ecological consequences of artificial night lighting. Island Press, Washington

Ridsdill-Smith TJ (1991) Competition in dung-breeding insects. In: Bailey WJ, Ridsdill-Smith TJ (eds) Reproductive behaviour in insects-individuals and populations, 1 st edn. Chapman and Hall, Melbourne, pp 264-292

Ridsdill-Smith TJ, Edwards PB (2011) Biological control: ecosystem functions provided by dung beetles. In: RidsdillSmith TJ, Simmons LW (eds) Ecology and evolution of dung beetles, 1st edn. Wiley-Blackwell, Oxford, pp 245266. https://doi.org/10.1002/9781444342000.ch12

Ridsdill-Smith TJ, Hall GP, Craig GF (1982) Effect of population density on reproduction and dung dispersal by the dung beetle Onthophagus binodis in the laboratory. Entomol Exp Appl 32:80-85. https://doi.org/10.1111/j.15707458.1982.tb03184.x

Ripa SR, Rojas PS, Velasco G (1995) Releases of biological control agents of insect pests on Easter Island (Pacific Ocean). Entomophaga 40:427-440. https://doi.org/10. 1007/bf02373730

Rivera C, Wolff M (2007) Digitonthophagus gazella (Coleoptera: Scarabaeidae): distribución en América y dos nuevos registros para Colombia. Rev Colomb Entomol 33:190-192

Rougon D, Rougon C (1980) Le cleptoparasitisme en zone sahélienne: phénomène adaptatif d'insects Coléoptères Coprophages Scarabaidae aux climats arides et semiarides. Comptes Rendus des Séances L'Académie des Sci 291:417-419

Rowles AD, O'Dowd DJ (2007) Interference competition by Argentine ants displaces native ants: implications for biotic resistance to invasion. Biol Invasions 9:73-85. https://doi. org/10.1007/s10530-006-9009-5

Roy HE, Brown PMJJ (2015) Ten years of invasion: Harmonia axyridis (Pallas) (Coleoptera: Coccinellidae) in Britain. Ecol Entomol 40:336-348. https://doi.org/10.1111/een. 12203

Roy S, Lavine J, Chiaromonte F et al (2009) Multivariate statistical analyses demonstrate unique host immune responses to single and dual lentiviral infection. PLoS ONE. https://doi.org/10.1371/journal.pone.0007359

Ruokolainen L, Ranta E, Kaitala V, Fowler MS (2009) Community stability under different correlation structures of species' environmental responses. J Theor Biol 261:379-387. https://doi.org/10.1016/j.jtbi.2009.08.010

Sakai AK, Allendorf FW, Holt JS et al (2001) The population biology of invasive species. Annu Rev Ecol Syst 32:305-332. https://doi.org/10.1146/annurev.ecolsys.32. 081501.114037

Scheffler PY (2005) Dung beetle (Coleoptera: Scarabaeidae) diversity and community structure across three disturbance regimes in eastern Amazonia. J Trop Ecol 21:9-19. https:// doi.org/10.1017/S0266467404001683

Seymour J (1980) Dung beetles get a little help from their friends. Ecos 26:20-25

Shorrocks B, Rosewell J, Edwards K, Atkinson W (1984) Interspecific competition is not a major organizing force in many insect communities. Nature 310:310-312. https:// doi.org/10.1038/310310a0

Simberloff D (2014) Biological invasions: what's worth fighting and what can be won? Ecol Eng 65:112-121. https://doi. org/10.1016/j.ecoleng.2013.08.004

Slade EM, Mann DJ, Villanueva JF, Lewis OT (2007) Experimental evidence for the effects of dung beetle functional group richness and composition on ecosystem function in a tropical forest. J Anim Ecol 76:1094-1104. https://doi.org/ 10.1111/j.1365-2656.2007.01296.x

Stachowicz JJ, Terwin JR, Whitlatch RB, Osman RW (2002) Linking climate change and biological invasions: ocean warming facilitates nonindigenous species invasions. Proc Natl Acad Sci USA 99:15497-15500. https://doi.org/10. 1073/pnas.242437499

Strayer DL, Eviner VT, Jeschke JM, Pace ML (2006) Understanding the long-term effects of species invasions. Trends Ecol Evol 21:645-651. https://doi.org/10.1016/j.tree.2006. 07.007

Stricker KB, Hagan D, Flory SL (2015) Improving methods to evaluate the impacts of plant invasions: lessons from 40 years of research. AoB Plants 7:plv028. https://doi.org/ 10.1093/aobpla/plv028

Venables WN, Ripley BD (2002) Modern applied statistics with S, 4th edn. Springer, New York. https://doi.org/10.1007/ 978-0-387-21706-2

Verdú JR, Galante E (1997) Aphodius brasiliensis Castelnau (Coleoptera: Aphodidae): larval morphology and notes on biology. Coleopt Bull 51:378-383

Verdú JR, Cortez V, Ortiz AJ et al (2015) Low doses of ivermectin cause sensory and locomotor disorders in dung beetles. Sci Rep. https://doi.org/10.1038/srep13912

Vidaurre T, Noriega JA, Julieta Ledezma M (2008) First report on the distribution of Digitonthophagus gazella (Fabricius, 1787) (Coleoptera: Scarabeaidae) in Bolivia. Acta Zool Mex Nueva Ser 24:217-220

Vilà M, Hulme PE (2017) Impact of biological invasions on ecosystem services, 1st edn. Springer, Cham. https://doi. org/10.1007/978-3-319-45121-3

Vilà M, Basnou C, Pysek P et al (2010) How well do we understand the impacts of alien species on ecosystem services? A pan-European, cross-taxa assessment. Front Ecol Environ 8:135-144. https://doi.org/10.1890/080083

Wilson KA, Magnuson JJ, Lodge DM et al (2004) A long-term rusty crayfish (Orconectes rusticus) invasion: dispersal patterns and community change in a north temperate lake. Can J Fish Aquat Sci 61:2255-2266. https://doi.org/10.1139/f04-170

Yelenik SG, D'Antonio CM (2013) Self-reinforcing impacts of plant invasions change over time. Nature 503:517-520. https://doi.org/10.1038/nature 12798

Young OP (2007) Relationships between an introduced and two native dung beetle species (Coleoptera: Scarabaeidae) in Georgia. Southeast Nat 6:491-504. https://doi.org/10. 1656/1528-7092(2007)6[491:RBAIAT]2.0.CO;2

Zenni RD, Dickie IA, Wingfield MJ et al (2017) Evolutionary dynamics of tree invasions: complementing the unified framework for biological invasions. AoB Plants 9:plw085. https://doi.org/10.1093/aobpla/plw085

Zunino M, Barbero E (1993) Escarabajos, ganado, pastizales: algunas consideraciones deontologicas. Folia Entomol Mex 87:95-101 